\title{
Determination of Sulfhydryl and Disulfide Contents of Soybean 11S Globulin and Their Change by Lyophilization
}

\author{
Yuji Hoshi and Fumio Yamauchi \\ Department of Food Chemistry, Faculty of Agriculture, \\ Tohoku University, Sendai 980, Japan
}

Received February 8, 1983

\begin{abstract}
Sulfhydryl (SH) and disulfide (SS) contents of soybean $11 \mathrm{~S}$ globulin (var. Raiden) were determined by means of Ellman's reagent. The amounts of surface SH, internal SH, and SS bonds of $11 \mathrm{~S}$ globulin (not lyophilized) were $10.3,4.6$, and $17 \mathrm{~mol} / \mathrm{mol}$ protein, respectively. On the other hand, when the $11 \mathrm{~S}$ globulin was lyophilized, the surface and internal SH diminished to 5 and 3.6 $\mathrm{mol} / \mathrm{mol}$ protein, respectively, and the SS bonds increased to $20.1 \mathrm{~mol} / \mathrm{mol}$ protein. The result from sodium dodecyl sulfate polyacrylamide gel electrophoresis suggested the possibility that the newly formed SS bonds probably existed in each constituent subunit of $11 \mathrm{~S}$ globulin and/or between the intermediary subunits which exist by nature. Differences and similarities between our result and those obtained by various workers were also discussed.
\end{abstract}

Eleven S globulin is the major storage protein of soybean seeds and has intermediary subunits (IS; MW 58,000 63,000), disulfidebonded acidic (MW 37,000 45,000) and basic (MW 21,000 22,500) subunits, and is composed of 6 IS's. ${ }^{1)}$ We have studied the effects of relative humidity on soybean $11 \mathrm{~S}$ globulin (var. Raiden), and it was found that SS bonds are closely related to the aggregation of lyophilized $11 \mathrm{~S}$ globulin with humidity. ${ }^{2,3)}$ Furthermore, sulfhydryl and disulfide groups have been implicated in the formation of SS polymers, heat denaturation, and intersubunit association of the protein. ${ }^{4)}$ Mori et al. have reported that there are differences in $\mathrm{SH}$ contents among cultivars. ${ }^{5)}$ Precise SH and SS contents on var. Raiden which we have used have seldom been reported. Therefore, we determined the SH and SS contents of $11 \mathrm{~S}$ globulin (var. Raiden), examining the determining method. Furthermore, since we have used a lyophilized $11 \mathrm{~S}$ globulin in a series of studies and the SH and SS contents were expected to change after lyophilization, the effects of lyophilization on the SH and SS contents of the proteins were also investigated.

\section{MATERIALS AND METHODS}

Materials. Soybean seeds (var. Raiden, $1981 \mathrm{crop}$ ) were stored at $5^{\circ} \mathrm{C}$, ground with a coffee mill, screened through a 60 mesh sieve, and defatted with hexane. Bovine serum albumin (BSA, fraction five) was purchased from Nakarai Chemicals Co., Ltd. Soybean trypsin inhibitor (STI) was purchased from Sigma Chemical Co., St. Louis (U.S.A.). Dithiothreitol (DTT), 2mercaptoethanol (2-ME), 5,5'-dithio-bis-(2-nitrobenzoic acid) (DTNB), sodium dodecyl sulfate (SDS) and Coomassie Brilliant Blue G-250 were specially prepared reagents and all other reagents were of the highest grade, obtained from Nakarai Chemicals Co., Ltd. Guanidine hydrochloride was recrystallized from methanol. Sepharose 4B and Sephadex G-25 were purchased from Pharmacia Fine Chemicals.

Preparation of $11 \mathrm{~S}$ globulin. Defatted soybean meals were extracted with $0.03 \mathrm{M}$ Tris- $\mathrm{HCl}$ buffer $(\mathrm{pH} 8.0)$ containing $0.01 \mathrm{M} 2-\mathrm{ME}$ and $0.001 \mathrm{M}$ ethylenediaminetetra acetic acid disodium salt (EDTA-2Na) (meal:buffer, $1: 20)$ for $1 \mathrm{hr}$ and centrifuged $(10,000 \mathrm{rpm}$ for $20 \mathrm{~min}$ at $20^{\circ} \mathrm{C}$ ). The extract was adjusted to $\mathrm{pH} 6.4$ with $2 \mathrm{~N} \mathrm{HCl}$ and stirred for $1 \mathrm{hr}$ at $5^{\circ} \mathrm{C}^{6)}$ The suspension was centrifuged $\left(10,000 \mathrm{rpm}, 20 \mathrm{~min}, 5^{\circ} \mathrm{C}\right)$ to precipitate the crude $11 \mathrm{~S}$ globulin and washed with $0.03 \mathrm{M}$ Tris- $\mathrm{HCl}$ buffer $(\mathrm{pH}$ 6.4) two times. The crude $11 \mathrm{~S}$ globulin was dissolved in a phosphate buffer $\left(2.6 \mathrm{mM} \mathrm{KH}_{2} \mathrm{PO}_{4}, 32.5 \mathrm{mM} \mathrm{K}_{2} \mathrm{HPO}_{4}\right.$, $0.4 \mathrm{M} \mathrm{NaCl}, 0.01$ м 2-ME, 0.001 м EDTA-2Na, $0.05 \%$ $\mathrm{NaN}_{3}, \mathrm{pH}$ 7.6) and left overnight at $5^{\circ} \mathrm{C}$ (the standard 
buffer hereafter means this buffer and the phosphate buffer means the standard buffer without 2-ME). The crude 11S globulin was further purified by ammonium sulfate fractionation essentially according to the method of Wolf et al. ${ }^{7)}$ To the crude $11 \mathrm{~S}$ globulin solution ammonium sulfate was added to $51 \%$ saturation. The supernatant was adjusted to $66 \%$ saturation with ammonium sulfate and the precipitate of $11 \mathrm{~S}$ globulin was dissolved in the standard buffer (stock solution). An aliquot of the stock solution was dialyzed against the standard buffer overnight and submitted to gel filtration of Sepharose 4B in the phosphate buffer, and the rest was dialyzed against water and then lyophilized. After lyophilization, determinations were carried out promptly.

Determination of sulfhydryl groups. The method was essentially that described by Ellman. ${ }^{8)}$ One $\mathrm{ml}$ of a protein solution (about $0.2 \%$ protein concentration) was mixed with $2 \mathrm{ml}$ of the phosphate buffer. To this mixture $0.05 \mathrm{ml}$ of DTNB solution ( $36,9 \mathrm{mg}$ of DTNB dissolved in $10 \mathrm{ml}$ of a phosphate buffer with ionic strength $0.1, \mathrm{pH} 7.0$ ) was added. In the case of the determination of the sulfhydryl content in the presence of denaturants, $1 \mathrm{ml}$ of a protein solution was mixed with $2 \mathrm{ml}$ of the phosphate buffer containing $6 \mathrm{M}$ guanidine hydrochloride. To this solution $0.05 \mathrm{ml}$ of DTNB solution was added. Since the color developed within $5 \mathrm{~min}$, the absorbance at $412 \mathrm{~nm}$ was measured $10 \mathrm{~min}$ later. The absorbance is expressed as $\mathrm{SH} \mathrm{mol} / \mathrm{mol}$ protein, using the molecular extinction coefficient $(13,600 \mathrm{M} / \mathrm{cm})$ for the calculation. Protein concentration (M) was determined from measurement of absorbance at $280 \mathrm{~nm}$, using the value of $8.04\left(E_{1}^{1 \%} \mathrm{~cm}\right)^{9)}$ and the molecular weight of $360,000 .^{1)}$ The $\mathrm{SH}$ value determined in the absence of the denaturant was defined as the surface $\mathrm{SH}$ and that in the presence of the denaturant was defined as the total $\mathrm{SH}$. The $\mathrm{SH}$ value after subtracting the surface $\mathrm{SH}$ from the total $\mathrm{SH}$ was defined as the internal SH.

Determination of disulfide bonds. Two $\mathrm{ml}$ of a protein solution (about $0.2 \%$ protein concentration) was mixed with $4 \mathrm{ml}$ of the phosphate buffer containing $9 \mathrm{M}$ guanidine hydrochloride. To the mixture, $16 \mathrm{mg}$ DTT was added, and then the protein was completely reduced for $4 \mathrm{hr}$ under $\mathrm{N}_{2}$ gas at room temperature. After reduction, the solution was submitted to gel filtration on Sephadex G-25 equilibrated with $0.03 \mathrm{M}$ Tris- $\mathrm{HCl}$ buffer $(0.01 \mathrm{M}$ EDTA$2 \mathrm{Na}, 0.05 \% \mathrm{NaN}_{3}, 4 \mathrm{~m}$ guanidine hydrochloride, $\mathrm{pH} 8.0$ ) to eliminate DTT. The effluents were collected in $5 \mathrm{ml}$ fractions and the absorbance of each fraction was monitored at $280 \mathrm{~nm}$. The fractions containing protein were submitted to $\mathrm{SH}$ determination as described above. Half of the value after subtracting the total $\mathrm{SH}$ from this obtained value was defined as the SS content. All the glass vessels were washed with $0.001 \mathrm{M}$ EDTA-2Na solution and then washed with distilled water before deter- mining the SH or SS contents.

Electrophoresis. Disc gel electrophoresis was performed in a $6.5 \%$ polyacrylamide gel according to Ornstein and Davis. ${ }^{10,11)}$ SDS polyacrylamide gel electrophoresis was carried out in a $8 \%$ gel according to Swank et al. ${ }^{12)}$ All gels were stained with Coomassie Brilliant Blue G-250 and destained by diffusion in $7.5 \% \mathrm{CH}_{3} \mathrm{COOH}-5 \% \mathrm{CH}_{3} \mathrm{OH}-$ water.

\section{RESULTS}

\section{SH Contents}

Before determining the $\mathrm{SH}$ content of the $11 \mathrm{~S}$ globulin, we examined whether the determining method described in MATERIALS AND Methods was valid. Cysteine and BSA were used as standard materials. The results are shown in Table I. Cysteine $(0.0129 \mathrm{~g})$ was dissolved in $1000 \mathrm{ml}$ of the phosphate buffer $\left(1.06 \times 10^{-5} \mathrm{M}\right)$. When this cysteine solution was determined with DTNB, the SH content was $1.06 \times 10^{-5} \mathrm{M}$ in the absence of guanidine hydrochloride and was $1.05 \times 10^{-5} \mathrm{M}$ in the presence of guanidine hydrochloride. Further, when BSA was determined with DTNB, the SH content was $0.57 \mathrm{~mol} / \mathrm{mol}$ protein as surface $\mathrm{SH}$ and was $0.6 \mathrm{~mol} / \mathrm{mol}$ protein as total $\mathrm{SH}$. The molecular weight of 66,000 and $E_{1}^{1 \%} \mathrm{~cm}$ of 6.6 were used for calculation. ${ }^{13)}$ The $\mathrm{SH}$ contents of BSA agreed with the reference. ${ }^{13)}$ From these results, the validity of the determining method was verified.

An aliquot of the stock solution was submitted to a gel filtration on Sepharose 4B. Although 2-ME was used during the extraction and ammonium fractionation, 2-ME had to be completely eliminated before the determination of the SH groups of the 11S globulin.

Table I. Concentrations of SH AND SS Groups Determined WITH DTNB

\begin{tabular}{cccc}
\hline & & $\begin{array}{c}\text { Cysteine } \\
(\mathrm{M})\end{array}$ & $\begin{array}{c}\text { BSA } \\
(\mathrm{mol} / \mathrm{mol} \text { protein })\end{array}$ \\
\hline \multirow{2}{*}{$\mathrm{SH}$} & $\left(-\mathrm{GuHCl}^{a}\right)$ & $1.06 \times 10^{-5}$ & 0.57 \\
& $\left(+\mathrm{GuHCl}^{a}\right)$ & $1.05 \times 10^{-5}$ & 0.60 \\
\multirow{2}{*}{$\mathrm{SS}$} & & & 16.8 \\
\hline
\end{tabular}

a $\mathrm{GuHCl}$, guanidine hydrochloride. 


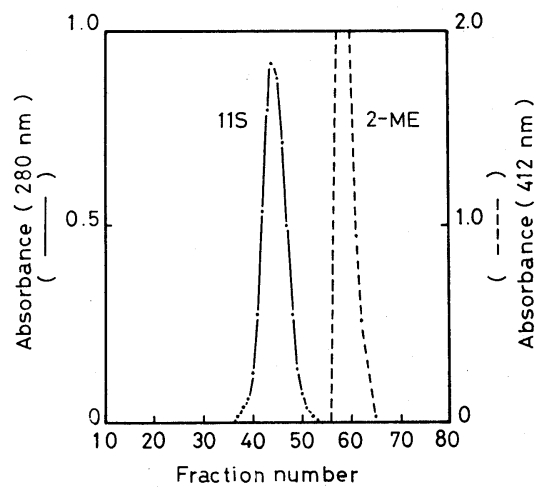

Fig. 1. Gel Filtration Pattern of Mixture of $11 \mathrm{~S}$ Globulin and 2-ME on Sepharose 4B.

A column of Sepharose $4 \mathrm{~B}(1.7 \times 95 \mathrm{~cm})$ was eluted with the phosphate buffer in $3 \mathrm{ml}$ fractions. Eleven $\mathrm{S}$ globulin was detected by the absorbance at $280 \mathrm{~nm}$ and $2-\mathrm{ME}$ at $412 \mathrm{~nm}$, reacted with DTNB.

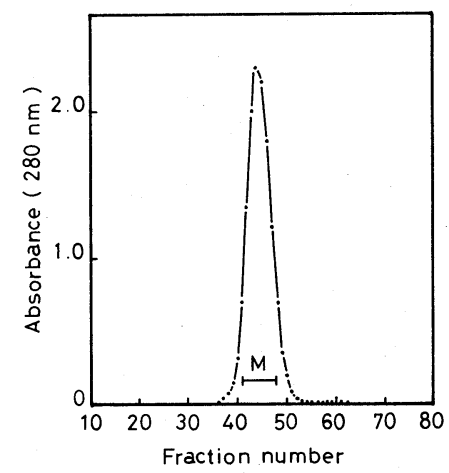

FIG. 2. Chromatogram of $11 \mathrm{~S}$ Globulin by Gel Filtration.

A column (Sepharose $4 \mathrm{~B}, 1.7 \times 95 \mathrm{~cm}$ ) was eluted with the phosphate buffer in $3 \mathrm{ml}$ fractions.

As shown in Fig. 1, 11S globulin eluted in fractions 36 53 and 2-ME eluted in fractions $56 \sim 65$. Thus, $2-\mathrm{ME}$ could be completely removed from the $11 \mathrm{~S}$ globulin. A representative elution pattern of the $11 \mathrm{~S}$ globulin which was prepared from the defatted meals and not lyophilized during the preparation procedure is shown in Fig. 2. Fractions $41 \sim 48$ (underlined part, $\mathrm{M}$ fraction) were collected. Polyacrylamide gel electrophoretic patterns of the $M$ fraction are shown in Fig. 3. In the Davis system, bands of $11 \mathrm{~S}$ globulin and $\overline{7 \mathrm{~S}}$ globulin were observed (Fig. 3a). Eleven S globu-

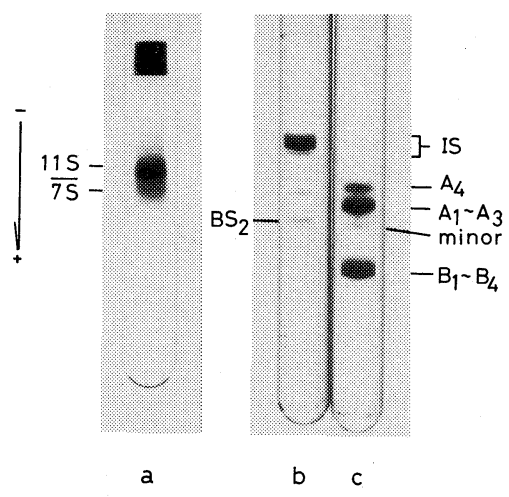

FIG. 3. Polyacrylamide Gel Electrophoretic Patterns of 11S Globulins.

Electrophoretic patterns of $M$ fraction in Fig. 2 in the Davis system (a), in an SDS system without 2-ME (b) and with 2-ME (c).

TABlE II. SH AND SS CONTENTS OF $11 \mathrm{~S}$ GLOBULIN

\begin{tabular}{lcc}
\hline & $\begin{array}{c}\text { 11S Globulin } \\
\text { (Not lyophilized) } \\
\text { (mol/mol protein) }\end{array}$ & $\begin{array}{c}\text { 11S Globulin } \\
\text { (Lyophilized) }\end{array}$ \\
\hline Surface SH & 10.3 & 5.0 \\
Internal SH & 4.6 & 3.6 \\
Total SH & 14.9 & 8.6 \\
SS & 17.0 & 20.1 \\
\hline
\end{tabular}

lin is the dimer of $\overline{7 \mathrm{~S}}$ globulin and $11 \mathrm{~S}$ globulin dissociates into $\overline{7 \mathrm{~S}}$ globulin in low ionic strengths. Because of the low ionic strength in the Davis system, $\overline{7 \mathrm{~S}}$ globulin occurred during electrophoresis. Figures $3 \mathrm{~b}$ and $\mathrm{c}$ show SDS polyacrylamide gel electrophoretic patterns in the absence and presence of 2-ME, respectively. In Fig. 3b, an intermediary subunit band was observed as a predominant band besides two minor bands. One of the two minor bands might be an acidic subunit which Iyengar et al. ${ }^{14)}$ have called the "free" acidic subunit and the other might be the dimer of basic subunits $\left(\mathrm{BS}_{2}\right)$ reported by Mori et al. ${ }^{15)}$ Acidic subunits $\left(A_{1} \sim A_{4}\right)$ and basic subunits $\left(B_{1} \sim B_{4}\right)$ of $11 \mathrm{~S}$ globulin newly appeared in the presence of 2-ME as shown in Fig. 3c. The minor band (minor) which was reported by Kitamura et al. ${ }^{16)}$ was also observed. The $\mathrm{SH}$ contents of the purified $11 \mathrm{~S}$ globulin are sum- 


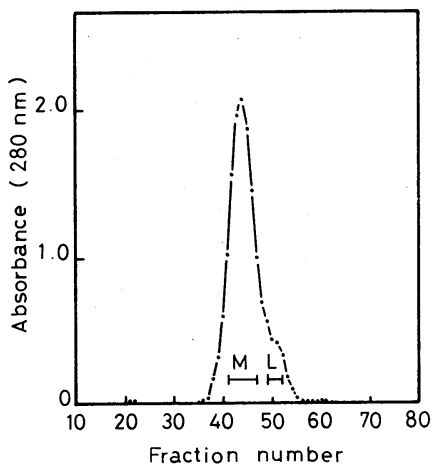

FIG. 4. Chromatogram of Lyophilized 11S Globulin by Gel Filtration.

A column (Sepharose $4 B, 1.7 \times 95 \mathrm{~cm}$ ) was eluted with the phosphate buffer in $3 \mathrm{ml}$ fractions.

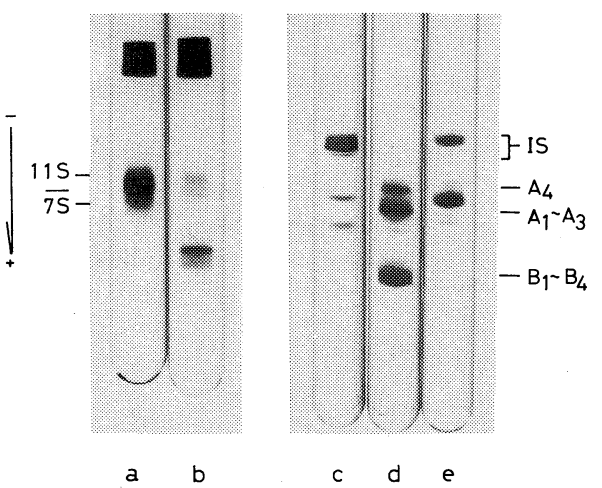

FIG. 5. Polyacrylamide Gel Electrophoretic Patterns of Lyophilized 11S Globulins.

Electrophoretic patterns of $\mathrm{M}$ fraction (a) and L fraction (b) in Fig. 4 in the Davis system. Electrophoretic patterns of the M fraction in the SDS system without 2-ME (c), with 2-ME (d) and L fraction without 2-ME (e).

marized in Table II. The surface $\mathrm{SH}$ was $10.3 \mathrm{~mol} / \mathrm{mol}$ protein, the internal $\mathrm{SH}$ was $4.6 \mathrm{~mol} / \mathrm{mol}$ protein, and the total $\mathrm{SH}$ was $14.9 \mathrm{~mol} / \mathrm{mol}$ protein. A portion from the stock solution was lyophilized and redispersed in the phosphate buffer. The elution pattern on Sepharose 4B, the electrophoretic patterns, and $\mathrm{SH}$ contents of this sample are shown in Figs. 4,5, and Table II, respectively. Figure 4 shows that low molecular weight species occurred (fractions $49 \sim 55$ ) besides the main peak (fractions $36 \sim 47$ ). Figure 5 shows electrophoretic patterns of each underlined part

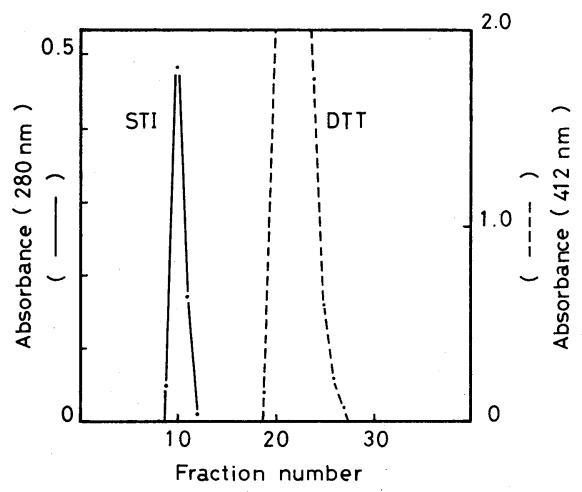

FIG. 6. Gel Filtration Pattern of a Mixture of STI and DTT on Sephadex G-25.

A column of Sephadex G-25 $(2.5 \times 20 \mathrm{~cm})$ was eluted with $0.03 \mathrm{M}$ Tris- $\mathrm{HCl}$ buffer $\left(10^{-2} \mathrm{M}\right.$ EDTA-2 $\mathrm{Na}, 0.05 \% \mathrm{NaN}_{3}$, $4 \mathrm{M}$ guanidine hydrochloride, $\mathrm{pH} 8.0$ ) in $5 \mathrm{ml}$ fractions. STI was detected by the absorbance at $280 \mathrm{~nm}$ and DTT at $412 \mathrm{~nm}$, reacted with DTNB.

(fractions $41 \sim 47, \quad M$ fraction; fractions $49 \sim 52$, L fraction). As shown in Fig. 5a, the $\mathrm{M}$ fraction gave $11 \mathrm{~S}$ and $\overline{7 \mathrm{~S}}$ globulin bands like Fig. $3 \mathrm{a}$ and the $\mathrm{L}$ fraction gave faster migrant bands than $11 \mathrm{~S}$ and $\overline{7 \mathrm{~S}}$ globulin. SDS polyacrylamide gel electrophoretic patterns of the $M$ fraction are shown in Fig. 5c (-ME) and Fig. 5d $(+\mathrm{ME})$ and were the same as those of Fig. 3b and c. Fig. 5e shows the electrophoretic pattern of the $\mathrm{L}$ fraction. IS and acidic subunits (mainly $A_{1} \sim A_{3}$ ) bands were observed. The $\mathrm{SH}$ contents of the $\mathrm{M}$ fraction (11S globulin) were $5.0 \mathrm{~mol} / \mathrm{mol}$ protein as surface $\mathrm{SH}, 3.6 \mathrm{~mol} / \mathrm{mol}$ protein as internal $\mathrm{SH}$, and $8.6 \mathrm{~mol} / \mathrm{mol}$ protein as total $\mathrm{SH}$.

\section{SS Contents}

Before determining the SS content of the $11 \mathrm{~S}$ globulin, the validity of the determining method of SS content was examined with BSA as the standard protein. The results are shown in Table I. The SS content of BSA was $16.8 \mathrm{~mol} / \mathrm{mol}$ protein and agreed well with the reference. ${ }^{17)}$

Determination of the 11S globulin was carried out. Two $\mathrm{ml}$ of the underlined parts in Fig. 2 was completely reduced and the solution was submitted to a gel filtration of Sephadex 
G-25. As shown in Fig. 6, DTT could be eliminated from STI (MW 21,500). Since the molecular weights of the subunits of $11 \mathrm{~S}$ globulin were $21,000 \sim 45,000$, DTT could be removed from $11 \mathrm{~S}$ globulin subunits with this gel filtration. The SS contents of the $11 \mathrm{~S}$ globulin were summarized in Table II. The SS content of the $11 \mathrm{~S}$ globulin was $17 \mathrm{~mol} / \mathrm{mol}$ protein and of the lyophilized $11 \mathrm{~S}$ globulin increased to $20.1 \mathrm{~mol} / \mathrm{mol}$ protein.

\section{DISCUSSION}

Several authors have been reported the sulfhydryl, disulfide, and half cystine contents of $11 \mathrm{~S}$ globulin by various methods. ${ }^{4,5,18 \sim 21)}$ Results, however, are different among the authors and $\mathrm{SH}$ and $\mathrm{SS}$ contents have seldom been reported on var. Raiden ${ }^{5)}$ which we have used in a study of the effect of relative humidity on soybean proteins. ${ }^{2,3)}$ Therefore, we determined the $\mathrm{SH}$ and SS contents of $11 \mathrm{~S}$ globulin (var. Raiden) by means of DTNB. Diez et al. have reported that DTNB was the most useful reagent for the determination of $\mathrm{SH}$ contents. ${ }^{13)}$ The $\mathrm{SH}$ values obtained for cysteine and BSA agreed well with the calculated value and the reference. ${ }^{13,17)}$ The $\mathrm{SH}$ groups of BSA are located on the surface of the protein ${ }^{17)}$ and the SH content of BSA (fraction five) has been reported to be $0.57 \mathrm{~mol} / \mathrm{mol}_{\text {protein. }}{ }^{13)}$ Furthermore, the SS content of BSA is $17 \mathrm{~mol} / \mathrm{mol}$ protein. ${ }^{17)}$ The determining method we used was useful enough to determine accurate $\mathrm{SH}$ and $\mathrm{SS}$ contents of proteins.

When the $11 \mathrm{~S}$ globulin was prepared from defatted soybean meal in the presence of 2$\mathrm{ME}$, the surface and internal SH contents were 10.3 and $4.6 \mathrm{~mol} / \mathrm{mol}$ protein, respectively. When soybean $7 \mathrm{~S}$ and $11 \mathrm{~S}$ globulin are prepared, 2-ME has been usually used since 2-ME dissociates disulfide polymers and raises extractability. SS bonds which locate on the surface may be cleaved by 2-ME used in the protein preparation. Simard et al. have reported that $11 \mathrm{~S}$ globulin (cultivar not given) has $1.1 \mathrm{~mol} / \mathrm{mol}$ protein as surface $\mathrm{SH}$,
$4.5 \mathrm{~mol} / \mathrm{mol}$ protein as internal $\mathrm{SH}$, and $5 \mathrm{~mol} / \mathrm{mol}$ protein as surface $\mathrm{SS}^{20}$ ) If the surface SS $(5 \mathrm{~mol})$ is cleaved, the surface $\mathrm{SH}$ becomes $11.1 \mathrm{~mol} / \mathrm{mol}$ protein and this value is similar to our result. Furthermore, the internal $\mathrm{SH}$ contents also agree with each other. On the other hand, Mori et al. have reported that there are differences in $\mathrm{SH}$ contents of $11 \mathrm{~S}$ globulin among soybean cultivars and var. Raiden has $0.5 \mathrm{~mol} / \mathrm{mol}$ protein as surface $\mathrm{SH}$ and $1.4 \mathrm{~mol} / \mathrm{mol}$ protein as internal $\mathrm{SH}^{5)}$ Draper et al. have reported that $11 \mathrm{~S}$ globulin (cultivar not shown) has $1.7 \mathrm{SH}$ groups only in the interior region. ${ }^{4)}$ These discrepancies may be due to the differences in preparation methods or cultivars. Furthermore, it may also be that the differences in determination procedures caused these discrepancies. In practice most of the surface $\mathrm{SH}$, however, seemed to exist as SS bonds in a protein body. The SH groups were hard to reoxidize into SS bonds in our preparation method because of the EDTA-2Na contained in the preparation and determination system, when the SS bonds were once cleaved.

When the 11S globulin was lyophilized, the surface and internal $\mathrm{SH}$ diminished to 5 and $3.6 \mathrm{~mol} / \mathrm{mol}$ protein, respectively. About 2.6 and $0.5 \mathrm{~mol} / \mathrm{mol}$ protein SS bonds were newly formed on the surface and in the interior region, respectively. Differences between Figs. $3 \mathrm{~b}$ and $5 \mathrm{c}$ were almost not observed. The newly formed SS bonds probably existed in each constituent subunit and/or between the intermediary subunits, which exist by nature. When the 11S globulin was lyophilized, gel filtration study showed that species with low molecular weights (L fraction) were formed (Fig. 4). SDS polyacrylamide gel electrophoresis showed that IS and acidic subunits $\left(A_{1} \sim A_{3}\right)$ were contained in the $L$ fraction (Fig. 5e). This showed that a part of the 11S globulin dissociated into IS and its constituent subunits during lyophilization. Since the isoelectric points of basic subunits are near the $\mathrm{pH}$ value of the phosphate buffer, dissociated basic subunits were probably precipitated and not observed in SDS polyacrylamide gel elec- 
trophoresis. The reason why the $\mathrm{A}_{4}$ subunit was observed to such a small extent is not known yet. Figures $3 \mathrm{a}$ and $5 \mathrm{a}$ showed that there are no differences among the $11 \mathrm{~S}$ globulins in each underlined part (Figs. 2 and 4).

The SS contents of the 11S globulin were 17 (not lyophilized) and 20.1 (lyophilized) $\mathrm{mol} / \mathrm{mol}$ protein, respectively. The sum of the total $\mathrm{SH}$ and twice as many as the amount of SS bonds was $48.9 \mathrm{~mol} / \mathrm{mol}$ protein. Catsimpoolas et al. have reported that $11 \mathrm{~S}$ globulin has $44 \pm 6$ half cystine residues (MW 350,000). ${ }^{18)}$ Draper et al. have also reported that $11 \mathrm{~S}$ globulin has 41.8 half cystine residues (MW 320,000). ${ }^{4)}$ Further, 42 half cystine residues have been reported by Badley et al. (MW 320,000). ${ }^{21)}$ When these values are estimated on the basis of MW 360,000, 11 S globulin should contain $45 \pm 6,47$, and 47 half cystine residues, respectively. These values agree with our value. On the other hand, Fukushima ${ }^{19)}$ and Simard et al. ${ }^{20)}$ have reported that $11 \mathrm{~S}$ globulin (Fukushima, var. Tsurunoko; Simard, not shown) have 36 and 43 half cystine residues (MW 360,000), respectively. These values are slightly lower than ours and this difference may be due to preparation procedures and/or cultivars.

\section{REFERENCES}

1) K. Kitamura, T. Takagi and K. Shibasaki, Agric. Biol. Chem., 40, 1837 (1976).
2) Y. Hoshi, F. Yamauchi and K. Shibasaki, Agric. Biol. Chem., 46, 1513 (1982).

3) Y. Hoshi and F. Yamauchi, Agric. Biol. Chem., 47, 1473 (1983).

4) M. Draper and N. Catsimpoolas, Cereal Chem., 55, 16 (1978).

5) T. Nakamura, S. Utsumi, H. Harada, K. Kitamura and T. Mori, Abstracts of Papers, Meeting of Agricultural Chemical Society of Japan, 1982, p. 8.

6) V. H. Thanh, K. Okubo and K. Shibasaki, Plant Physiol., 56, 19 (1975).

7) W. J. Wolf, G. E. Babcock and A. K. Smith, Arch. Biochem. Biophys., 99, 265 (1962).

8) G. L. Ellman, Arch. Biochem. Biophys., 82, 70 (1959).

9) K. Koshiyama, Int. J. Peptide Protein Res., 4, 167 (1972).

10) L. Ornstein, Ann. N. Y. Acad. Sci., 121, 321 (1964).

11) B. J. Davis, Ann. N. Y. Acad. Sci., 121, 404 (1964).

12) R. T. Swank and K. D. Munkress, Anal. Biochem., 39, 462 (1971).

13) M. J. Fernandez Diez, D. T. Osuga and R. E. Feeney, Arch. Biochem. Biophys., 107, 449 (1964).

14) R. B. Iyengar and P. Ravestein, Cereal Chem., 55, 325 (1981).

15) S. Utsumi, H. Inaba and T. Mori, Agric. Biol. Chem., 44, 1891 (1980).

16) K. Kitamura, Y. Toyokawa and K. Harada, Phytochem., 19, 1841 (1980).

17) R. Cecil, "The Protein," ed. by Neurath, Vol. 1, Academic Press, New York, London, 1963, p. 338.

18) N. Catsimpoolas, T. Berg and E. W. Mayer, Int. J. Peptide Protein Res., 3, 63 (1971).

19) D. Fukushima, Cereal Chem., 45, 203 (1968).

20) C. Simard and M. Bouler, Can. Inst. Food Sci. Technol. J., 11, 45 (1978).

21) R. A. Badley, D. A. Atkinson, H. Hauser, D. Oldani, J. P. Green and J. M. Stubbs, Biochim. Biophys. Acta, 412, 214 (1975). 